\section{DISEASES OF WOMEN.}

By Ten Teachers. Under the direction of Clifford White, M.D., B.S. (Lond.), F.R.C.P. (Lond.), F.R.C.S. (Eng.), F.C.O.G. Edited by Sir ComyNs Berkeley, Clifford White and Frank Cook. Sixth Edition. Edward Arnold \& Co., London. 1938. Price 18/- net.

In the group of teachers responsible for this edition changes have occurred, yet the work maintains the high standard of authoritative and up-to-date teaching established in previous editions. It is noteworthy that the system of revision by the authors has been even more thorough than heretofore.

On the subject of menstruation, a timely note of scepticism is sounded with regard to the over-enthusiastic acceptance of the results of endocrine therapy. Reference is also made to the confusion produced by the variety of trade names applied to the different hormones. A succinct account of the modern views concerning the physiology of menstruation is followed by an excellent account of the disorders of that function.

The various gynæcological conditions are considered in turn, neurasthenia and neurosis in relation to pelvic disorders are discussed, operations are briefly described, and, finally, an account is given of the methods of contraception and sterilization.

In every chapter, the confident note of authority prevails, but there is never any attempt to dogmatize. The illustrations are helpful; the book is a pleasure to read, and can be warmly recommended to all whose interests lie in the domain of gynæcology.

\section{THE RHEUMATIC DISEASES.}

A course of lectures arranged by the Medical Staff of the St. John's Institute of Physical Medicine. Edited by Sir Leonard HILl, M.B., LL.D., F.R.S., and PhIlIP EllmaN, M.D., M.R.C.P. Edward Arnold \& Co., London. 1938. Price $10 / 6$.

Sir William Willcox gives a very neat and concise introduction to this series of lectures in an ætiological and clinical survey of the rheumatic diseases.

He states clearly what is thought fairly generally that Poynton and Payne's incrimination of a streptococcus as the cause of acute rheumatism, although subject to a good deal of criticism by bacteriologists, may turn out to be very near the truth.
He justly praises Dr. Alison Glover's official report on the rheumatic diseases in 1924, and gives a sketch of the various developments in the field of rheumatism since.

It can be justly said that all the articles which make up the book are informative and authoritative, and that the authors have kept a nice balance between theory and fact.

It is not possible to mention all the articles and one or two will be taken as representative.

Professor Leonard Findlay fairly puts the problem of the "Unitary theory" of acute rheumatism of children and the chronic rheumatic disorders of adult life; and makes some very apt remarks on the possibility and probability of rheumatic meningitis, pleurisy and peritonitis. He also mentions the "tuberculous rheumatism" of Poncet and Leriche and quotes a case of acute polyarthritis complicated by pericarditis in which the picture of rheumatic fever was closely simulated and where the correct diagnosis could only be made post-mortem.

It is particularly interesting to have such a case quoted from an authoritative source, as the present position of tuberculous rheumatism could be much clarified by such cases, and it is only one example of the way in which the book teems with interesting points.

Timbrell Fisher gives an interesting chapter on the pathology of rheumatoid arthritis and mentions the recently developed technique of arthrotomy and lavage, of which there is no doubt we shall hear more in the future.

A rather curious and unusual feature is the combination of two articles on the subject of pelvic sepsis in rheumatism, one by the late Mr. Martin Oldershaw and the other by Dr. C. A. Robinson. It is perhaps an example that could be followed with benefit, as the consideration of a subject from two angles is always of interest.

Radiology is one of the sheet anchors in chronic rheumatism, as in a branch of medicine where so much uncertainty exists, great dependence must be placed on the radiologist.

Dr. G. T. Calthrop has written an excellent article dealing with exactly the sort of things physicians want to know from 
radiologists, and dealing with them clearly. A full explanation is given of the " standard hand " technique and the separation of the various types of arthritis radiologically.

Drs. E. H. Koerner and E. P. Poulton deal with antistreptolysins and blood uric acid. They deal in detail with $\mathrm{E}$. W. Todd's well known work, and their own application of it, with notes on the effect of prontosil on the titres and their results in gout.

Sir Leonard Hill deals ably, as we would expect, with the physiological action of methods used in physical medicine and Dr. Ellman introduces a useful little chapter on drugs.

Dr. Bach has undertaken the work on muscular rheumatism and on hydrotherapy, probably two of the most difficult chapters to write, and has evidently taken great trouble with great success.

Every doctor interested in rheumatismand what doctor is not--should not only have this book but should refer to it constantly in the treatment of his cases of rheumatism.

\section{Forthcoming Medical Books.}

\section{J. \& A. CHURCHILL LTD.,}

1.04, Gloucester Place, Portman Square, London, W.1.

"Vitamins and Vitamin Deficiencies." Vol. I of a new work by Dr. Leslie Harris. The contents of this first volume comprise " History - Introduction Vitamin $\mathrm{B}_{1}$-Beri-beri." It contains 50 illustrations, some 2,000 references to literature, and will be issued at $8 \mathrm{~s}$. $6 \mathrm{~d}$.

"Recent Advances in Forensic Medicine," by Prof. Sydney Smith and Prof. John Glaister. This work has been increased in extent, the whole text thoroughly revised and a new chapter on Larval Infestation added. The illustrations will number 81 and the price will be $15 \mathrm{~s}$. Ready November.

"The Queen Charlotte's Textbook of Obstetrics" (5th Edition) will shortly be ready. This volume is the product of a team of specialists and each edition has increased in popularity. The work presents an up-to-date account of current obstetric practice. The price will be 21s.

"Clinical Bacteriology," by Dr. F. A. Knott, Director of the Bacteriological Department, and Lecturer in Bacteriology, Guy's Hospital. The scope of the book has been limited to the clinical applications of Bacteriology to everyday medicine. 60 useful illustrations enhance the text of 425 pages. It is hoped to publish this volume at about $15 \mathrm{~s}$.

A new, illustrated catalogue of Medical and Scientific publications has just been issued and a copy will gladly be sent upon application.

\section{J. B. LIPPINCOTT COMPANY,}

John Street, Adelphi, W.C.2.

"Experience in the Management of Fractures and Dislocations" (based on an Analysis of 4,390 cases). Under the General Editorship of Philip D. Wilson, M.D. 1,419 illustrations in the text of which 1,192 are line tracings of rœntgenograms in case reports. 1,036 pages. Index. Price 65s.

"Outline of Rontgen Diagnosis." An Orientation in the Basic Principles of Diagnosis by the Rœntgen Method, by Leo G. Rigler, B.S., M.B., M.D. Containing Pictorial Atlas presenting 254 illustrations shown in 227 figures, presented in drawings and reproductions of rœntgenograms. Figures 6 to 51 and 55 to 72 are drawings in an original technic by Jean E. Hirsch. Index. Price 30s.

"Before Your Baby is Born," by May E. Law, M.B., Ch.B. Illustrated. 6d. each.

"Anus, Rectum and Sigmoid Colon" (Diagnosis and Treatment), by Harry E. Bacon, M.D., F.A.C.S. Foreword by J. P. Lockhart-Mummery, M.A., M.B., B.Ch., F.R.C.S. (Eng.), Emeritus Surgeon, St. Mark's Hospital, London. Introduction by $W$. Wayne Babcock, M.D., Ll.D., F.A.C.S. 480 illustrations in the text mostly original by William Brown McNett. 855 pages. Index. Price 38 s. 